\title{
The Four Deaths of Joshua: Why the Septuagint is Pivotal for the Study of Joshua 24?
}

\section{Mäkipelto, Ville Joonas}

2017-06

Mäkipelto , V J 2017 , ' The Four Deaths of Joshua : Why the Septuagint is Pivotal for the

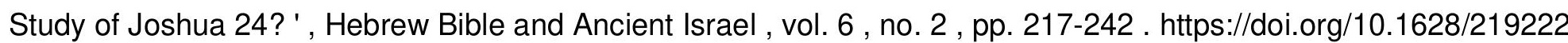

http://hdl.handle.net/10138/297900

https://doi.org/10.1628/219222717X15106587641508

publishedVersion

Downloaded from Helda, University of Helsinki institutional repository.

This is an electronic reprint of the original article.

This reprint may differ from the original in pagination and typographic detail.

Please cite the original version. 


\section{Hebrew Bible and Ancient Israel}

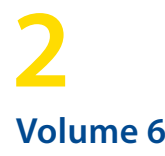
2017
Joshua 24

Thomas B. Dozeman

Introduction: The Current State of Scholarship

on Joshua 24 145-147

Konrad Schmid

Jews and Samaritans in Joshua 24 148-160

\section{Cynthia Edenburg}

Joshua 24: A Diaspora-oriented Overriding

of the Joshua Scroll 161-180

Joachim J. Krause

Hexateuchal Redaction in Joshua 181-202

Thomas Römer

The Date, Composition and Function of Joshua 24

in Recent Research. A Response to Joachim J. Krause,

Cynthia Edenburg, and Konrad Schmid 203-216

Ville Mäkipelto

The Four Deaths of Joshua: Why the Septuagint is Pivotal for the Study of Joshua $24 \quad 217-242$

\section{New Projects}

Emanuel Tov, The Publication of the Textual History of the Bible in Light of the Progress in Textual Scholarship 245-258 


\section{Hebrew Bible and Ancient Israel}

Herausgegeben von Gary N. Knoppers (Notre Dame IN), Oded Lipschits (Tel Aviv), Carol A. Newsom (Atlanta GA) und Konrad Schmid (Zürich) Redaktion: Phillip Michael Lasater (Zürich)

Die Annahme zur Veröffentlichung erfolgt schriftlich und unter dem Vorbehalt, dass das Manuskript nicht anderweitig zur Veröffentlichung angeboten wurde. Mit der Annahme zur Veröffentlichung überträgt der Autor dem Verlag das ausschließliche Verlagsrecht für die Publikation in gedruckter und elektronischer Form. Weitere Informationen dazu und zu den beim Autor verbleibenden Rechten finden Sie unter www.mohr.de/hebai. Ohne Erlaubnis des Verlags ist eine Vervielfältigung oder Verbreitung der ganzen Zeitschrift oder von Teilen daraus in gedruckter oder elektronischer Form nicht gestattet. Bitte wenden Sie sich an rights@mohr.de.

Redaktionsadresse

Professor Dr. Konrad Schmid

Theologische Fakultät der Universität Zürich

Kirchgasse 9

CH-8001 Zürich

Switzerland

E-mail: hebai@theol.uzh.ch

Online-Volltext

Im Abonnement für Institutionen und Privatpersonen ist der freie Zugang zum Online-Volltext enthalten. Institutionen mit mehr als 20.000 Nutzern bitten wir um Einholung eines Preisangebots direkt beim Verlag. Kontakt: elke. brixner@mohr.de. Um den Online-Zugang für Institutionen/Bibliotheken einzurichten, gehen Sie bitte zur Seite: www.ingentaconnect.com/register/ institutional. Um den Online-Zugang für Privatpersonen einzurichten, gehen Sie bitte zur Seite: www.ingentaconnect.com/register/personal

Verlag: Mohr Siebeck GmbH \& Co. KG, Postfach 2040, 72010 Tübingen Vertrieb erfolgt über den Buchhandel.

(C) 2017 Mohr Siebeck GmbH \& Co. KG, Tübingen

Die Zeitschrift und alle in ihr enthaltenen einzelnen Beiträge und Abbildungen sind urheberrechtlich geschützt. Jede Verwertung außerhalb der engen Grenzen des Urheberrechtsgesetzes ist ohne Zustimmung des Verlags unzulässig und strafbar. Das gilt insbesondere für Vervielfältigungen, Übersetzungen, Mikroverfilmungen und die Einspeicherung und Verarbeitung in elektronischen Systemen.

Satz: Martin Fischer, Tübingen.

Druck: Gulde-Druck, Tübingen.

ISSN 2192-2276 (Gedruckte Ausgabe)

ISSN 2192-2284 (Online-Ausgabe) 


\section{Ville Mäkipelto}

\section{The Four Deaths of Joshua: Why the Septuagint is Pivotal for the Study of Joshua 24}

The article reconstructs the textual growth of the death and burial accounts of Joshua (Josh 24:28-31, Judg 2:6-9) in the light of documented evidence preserved in the LXX and the MT. It is argued that LXX Josh 24:28-31 generally preserves the earliest extant version from which the others have been edited to various new contexts. The article then discusses some implications of this reconstruction for literary and redaction criticism of Josh 24 . Since redaction critics often neglect the LXX as a witness to an earlier Hebrew text, untenable conclusions have been advanced about the compositional history of Josh 24.

Keywords: Book of Joshua, Book of Judges, Septuagint, Textual history, Editorial history

\section{Introduction}

There are four differing accounts of the death and burial of Joshua in the textual witnesses to the Hebrew Bible. These are found in the Septuagint (LXX) and Masoretic (MT) versions of Josh 24:28-31 and Judg 2:6-9. The accounts are textually dependent on each other since they share the majority of their material word for word. ${ }^{1}$ A comparison of these four accounts, however, reveals several important differences, which illuminate the textual growth of the pericope. In this study, I seek to reconstruct this textual de-

1 These texts have been compared by several scholars as part of their larger studies, with no emerging consensus. See, for example, A. G. Auld, "Judges I and History: A Reconsideration," VT 25 (1975): 261-285; H. N. Rösel, "Die Überleitungen vom Josua ins Richterbuch," VT 30 (1980): 342-350; A. Rofé, "The End of the Book of Joshua," Henoch 4 (1982): 21; W.T. Koopmans, Joshua 24 as Poetic Narrative (JSOTSup 93; Sheffield: JSOT Press, 1990), 363-369; D. Jericke, "Josuas Tod und Josuas Grab. Eine redaktionsgeschichtliche Studie," $Z A W 108$ (1996): 347-361. At this point, it is important to compare the four versions in their own right without letting their larger contexts in Joshua-Judges play too much of a role in the textual analysis. Moreover, it has not yet been sufficiently discussed how the data available from the text-critical parallel versions could affect the methods of literary and redaction criticism. 
velopment. In addition, I will consider the implications of this text-critical reconstruction for literary (Literarkritik) and redaction criticism, since their practitioners have often overlooked the text-critical finding that the LXX in many cases reflects earlier Hebrew versions. ${ }^{2}$ Even though this study is based on a limited number of verses, it can be argued that a reliable model of the compositional history of Joshua 24 cannot be reconstructed without taking the LXX into account. ${ }^{3}$

The structure of this study is threefold. First, some initial remarks will be given on the LXX versions of the pericopes in order to draw conclusions about their Hebrew Vorlagen. Second, a text-critical evaluation of the four traditions will be performed. This will result in a hypothesis on their relationship and development. Finally, some implications for using the textcritical analysis of this pericope in literary and redaction criticism will be considered. It will be argued that textual criticism of Joshua 24 overlaps in many instances with literary and redaction criticism and that they should not be treated separately.

\section{The LXX as a witness to a variant Hebrew text}

In studying the early history of the Hebrew text, the usage of the LXX versions of Joshua and Judges is challenged by the absence of a critical Göttingen edition of either one. In Joshua, the Old Greek (OG) text is quite often found in Codex Vaticanus (B) and other manuscripts (most notably 120 129) be-

2 A neglect of the LXX is seen, for example, in the early commentary by M. Noth, Das Buch Josua (Tübingen: Mohr, 1938), 105-110. A recent example is an article by E. Aurelius, "Zur Entstehung von Josua 23-24," in Houses Full of All Good Things: Essays in Memory of Timo Veijola (ed. J. Pakkala and M. Nissinen; Helsinki: Finnish Exegetical Society, 2008), 95-114. In Aurelius' study, only one LXX variant is accepted as preserving an earlier Hebrew text. Also the monograph by M. N. van der Meer, Formation \& Reformulation: The Redaction of the Book of Joshua in the Light of the Oldest Textual Witnesses (VTSup 102; Leiden: Brill, 2004) should be noted. There a redaction-critical model based on the MT is kept strictly apart from the analysis of the textual witnesses. Such a separation is not, in my opinion, methodologically justifiable as I will attempt to show in this study. The study by van der Meer does not, however, deal with chapter 24. More on the neglect of the LXX in redaction criticism, see K. De Troyer, "Which Text Are We Using For Our Studies of Deuteronomistic Literature?" in Congress Volume Helsinki 2010 (VTSup 148; Leiden: Brill, 2010), 461-472.

3 This article stems from my research project in which the evidence from the various textual witnesses of Joshua 24 and related texts will be integrated into a literary and redaction critical discussion. The results of my research will be available in my monograph: V. Mäkipelto, "Uncovering Ancient Editing: Documented Evidence of Changes in Josh 24 and Related Text” (University of Helsinki dissertation, 2018). 
longing to the same group. ${ }^{4}$ Joshua 24:28-31 as given in the edition of Rahlfs is, in my judgment, a good estimation of the OG text. ${ }^{5}$ In Judges, the B-text and other manuscripts in the same group are in many instances influenced by the so-called kaige revision. ${ }^{6}$ The so-called Antiochian manuscripts are usually held to be the best witnesses for the OG. ${ }^{7}$ Judges 2:6-9 presents no such differences in the manuscripts of the LXX that would affect the reconstruction of its Hebrew Vorlage in instances where the four versions differ. Thus, the text of Rahlfs is a suitable starting point for this study. ${ }^{8}$

The translation techniques of Joshua and Judges vary. Seppo Sipilä has concluded that the translation technique of Joshua is situated between literalness and freedom while the LXX translation of Judges is quite literal. ${ }^{9}$ The freedom of the LXX Joshua translator is seen mainly in the flexibility in using varying translation equivalents for recurring Hebrew expressions and some grammatical structures. ${ }^{10}$ In our pericope, both translations quite faithfully present the components in their Hebrew Vorlagen.

Based on what we know so far of the translation technique of Joshua and Judges, it is important to highlight that the translators would not have intro-

4 On this consensus see, for example, L. Greenspoon, Textual Studies in the Book of Joshua (HSM 28; Atlanta: Scholars Press, 1983) and C. G. den Hertog, Studien zur griechischen Übersetzung des Buches Josua (Gießen: Justus-Liebig-Universität Dissertation, 1996). These MSS are, however, not free from errors and revisions and ideally every reading should be evaluated on a case by case basis.

5 This is corroborated by the early critical edition by M. L. Margolis, The Book of Joshua in Greek: According to the Critically Restored Text with an Apparatus Containing the Variants of the Principal Recensions and of the Individual Witnesses, Part V: Joshua 19:39-24:33 (Philadelphia: Annenberg Research Institute, 1992), 469-471 which is in these verses almost identical to the text of Rahlfs. It suggests only two corrections in the correct case of two proper names. These have, however, no implications for our study and will not be discussed here.

6 Kaige refers to early Jewish revisional activity, from the first century B.C. E. onwards, which aimed at bringing the Greek text closer to its Hebrew reference text. For kaige and other recensional developments in Judges, see W. R. Bodine, Greek Text of Judges: Recencional Developments (HSM 23; Atlanta: Scholars Press, 1980).

7 See, for example, J.M. Dines, The Septuagint (London: T\&T Clark, 2004), 17 and J. Trebolle Barrera, "Textual Variants in Joshua - Kings Involving the Terms 'People' and 'Israel'," in In the Footsteps of Sherlock Holmes: Studies in the Biblical Text in Honour of Anneli Aejmelaeus (ed. K. De Troyer, T. M. Law and M. Liljeström; Leuven: Peeters, 2014), 232.

8 However, A- and B-texts preserve a different version of verse 6. There, the OG-text is probably found in A but the matter is not yet settled.

9 Sipilä, Between, 193-212. Similarly also R. Sollamo, "Joosuan kirjan Septuagina-käännöksen luonteesta," TA 92 (1987): 191-198.

10 C. G. den Hertog, "Jesus. Josue / Das Buch Josua," in Septuaginta Deutsch. Erläuterungen und Kommentare. Band 1: Genesis bis 4. Makkabäer (ed. M. Karrer and W. Kraus; Stuttgart: Deutsche Bibelgesellschaft), 608-610. 
duced significant changes in relation to their Vorlagen. Hence, the most radical differences between the LXX and the MT (e.g. relocations, rewritings, omissions, large additions) cannot be attributed to the translator without exceptionally good reasons. ${ }^{11}$ It seems that the Hebrew texts in front of the translators of LXX Josh 24:28-31 and Judg 2:6-10 can be deduced with a good degree of certainty. These four verses use such common expressions and represent such literal translations that it seems highly probable that the major differences in relation to the MT were already present in their Hebrew Vorlagen and not introduced by the Greek translator.

\section{The textual growth of the passage}

There are several minor and major differences between the four versions of Joshua's death and burial. Firstly, the order in MT Josh 24:28-31 differs from the three other witnesses as the verse reporting the fidelity of the Israelites is situated after Joshua's death. Secondly, there is unique material in LXX Josh 24:31a reporting the burial of the flint knives and highlighting Joshua's active role as a leader in the exodus. Thirdly, the first verse differs in several details among all four versions. All of the variants are demonstrated in the table below. ${ }^{12}$

\begin{tabular}{|c|c|c|c|}
\hline Josh 24:28-31 (MT) & ${ }^{2}$ Josh 24:28-31 (LXX) & Judg 2:6-9 (MT) & $J u d g$ 2:6-9 (LXX A) \\
\hline 28 & 28 & 6 & 6 \\
\hline 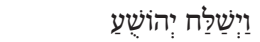 & 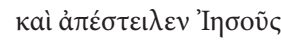 & 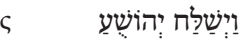 & 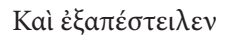 \\
\hline \multirow{4}{*}{ אֶת־־ֶָָם } & & & 'Iฤбoṽ \\
\hline & 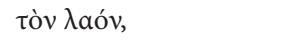 & אֶת־הָעָם & 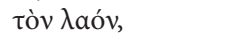 \\
\hline & 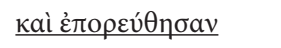 & 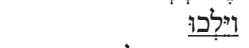 & $\underline{\text { кà } \alpha \dot{a} \pi \tilde{\eta} \lambda \theta \alpha \nu}$ \\
\hline & & 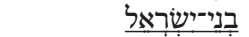 & oi viò̀ I $\sigma \rho a \eta \lambda^{13}$ \\
\hline
\end{tabular}

11 This point is aptly emphasized by Greenspoon, Textual, 379: “The OG translator rendered, to the best of his considerable abilities, the Hebrew text that lay before him. His knowledge of Hebrew and his fidelity to that Hebrew are to be rated far higher than the derogatory comments of some previous scholars would allow." See also E. Tov, "Literary Development of the Book of Joshua as Reflected in the MT, the LXX, and 4QJosh"," in The Book of Joshua (ed. E. Noort; Leuven: Peeters, 2012), 66-67.

12 In this study, plusses are plusses are underlined and differently formulated expressions are printed with a grey background. The words with no markings are similar in all of the four witnesses. Variation caused by the choices of different translation equivalents are not noted. As we compare four different texts, all the intricacies of the relationships of the texts cannot be displayed in the table.

13 "The sons of Israel" is missing from the B-text and some other Greek MSS. While the B-text seems to otherwise correct its reading of v. 6 towards the Hebrew text, the miss- 


\begin{tabular}{|c|c|c|c|}
\hline \multirow{4}{*}{ 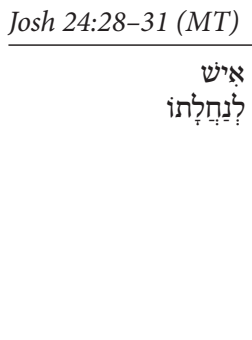 } & Josh 24:28-31 (LXX) & g 2:6-9 (MT) & Judg 2:6-9 (LXX A) \\
\hline & \multirow[t]{3}{*}{ 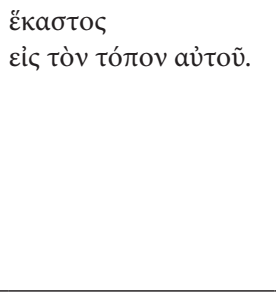 } & \multirow[b]{3}{*}{ 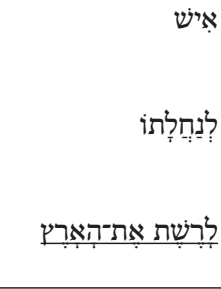 } & 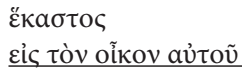 \\
\hline & & & 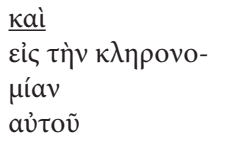 \\
\hline & & & 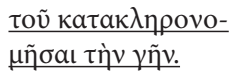 \\
\hline & 29 & 7 & 7 \\
\hline & 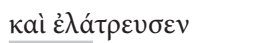 & 1ַוַיעַבְדבוּ הָעָם & 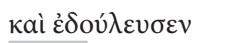 \\
\hline & $\operatorname{I\sigma \rho } \propto \eta \lambda$ & & ó 入aò \\
\hline & 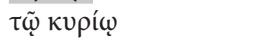 & אֶת־ייהוָה & 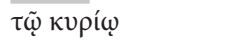 \\
\hline & 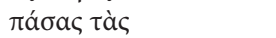 & 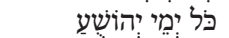 & 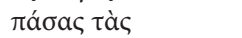 \\
\hline & 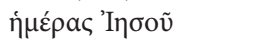 & & 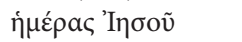 \\
\hline & 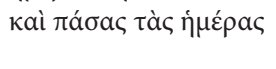 & 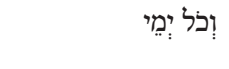 & 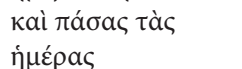 \\
\hline & $\tau \tilde{\omega} \nu \pi \rho \varepsilon \sigma \beta v \tau \varepsilon \dot{\varepsilon} \rho \omega \nu$ & הַזְקָנִים & $\tau \tilde{\omega} v \pi \rho \varepsilon \sigma \beta v \tau \varepsilon \dot{\rho} \rho \omega v$ \\
\hline & 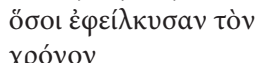 & אָשֶׁר הֶאֶריכוּ יָמִים & 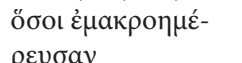 \\
\hline & 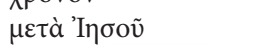 & אַחַרֵי יִיהוֹשוּעַ & $\mu \varepsilon \tau \grave{\alpha}$ 'I \\
\hline & 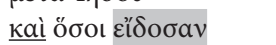 & אַשַַׁר רָאוּ & 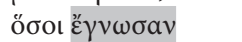 \\
\hline & 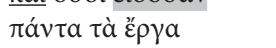 & 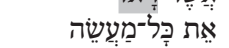 & 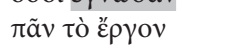 \\
\hline & кupíov, & 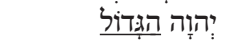 & 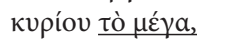 \\
\hline & 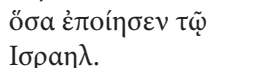 & 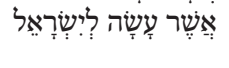 & 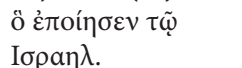 \\
\hline
\end{tabular}

2930

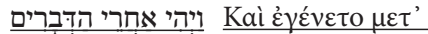

הָאל

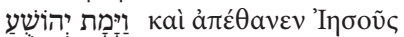

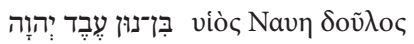
кupíov

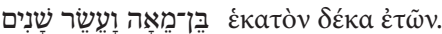

$8 \quad 8$

\section{8}

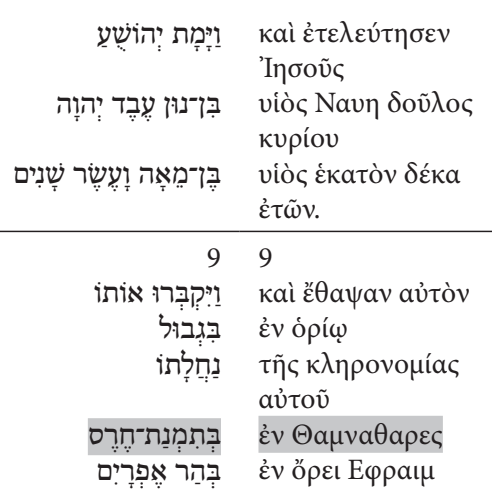

ing of "the sons of Israel" might be a feature of the OG. The matter, however, does not need to be settled here. 


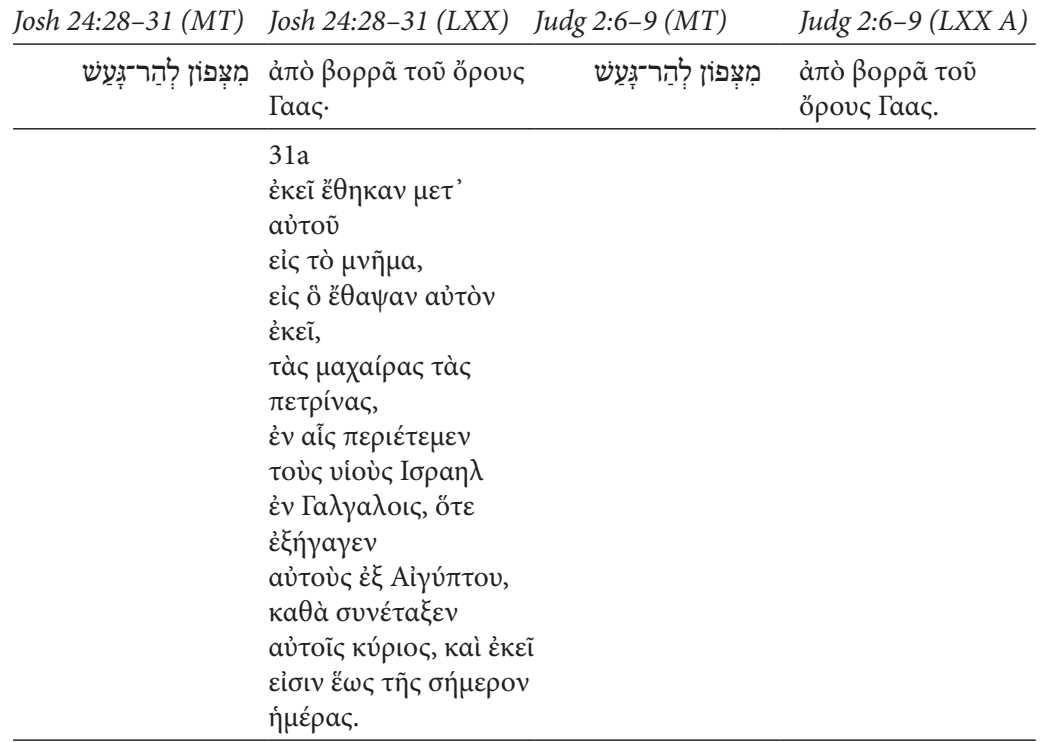

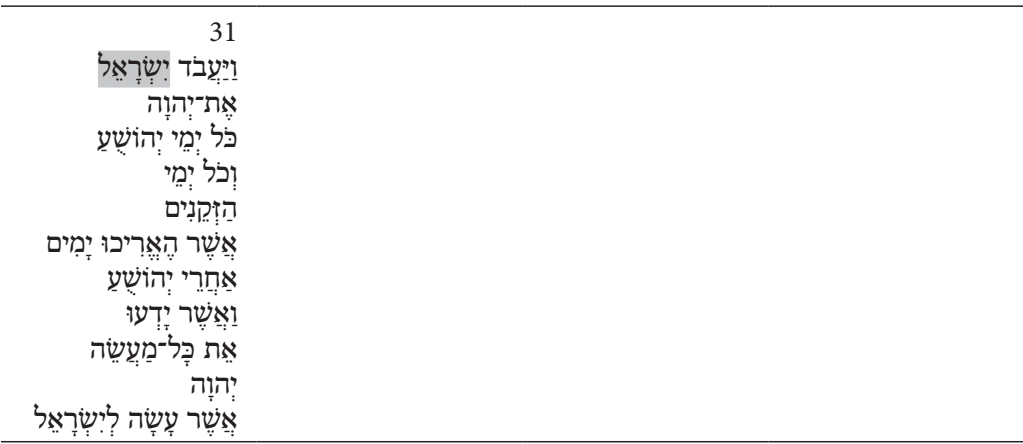

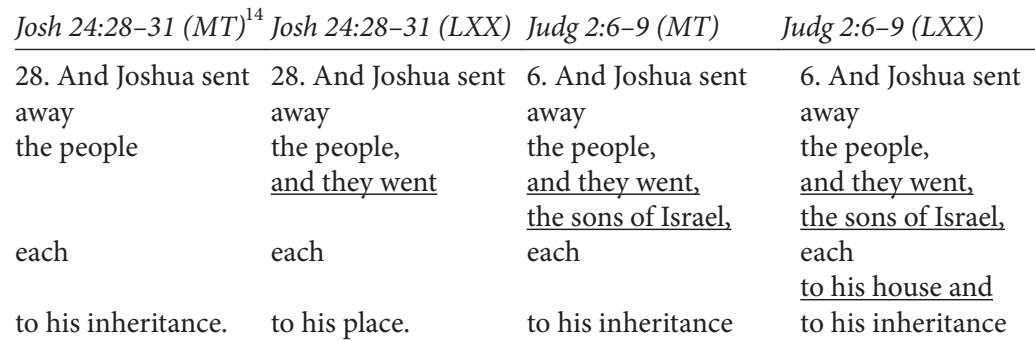

14 The translations are based on NRSV (MT) and NETS (LXX); however, I deviate from them in many instances in order to highlight the similarities and dissimilarities between the original Hebrew and Greek texts. 


\begin{tabular}{|c|c|c|c|}
\hline \multirow[t]{2}{*}{ Josh 24:28-31 (MT) J } & \multirow[t]{2}{*}{ Josh 24:28-31 (LXX) } & Judg 2:6-9 (MT) & Judg 2:6-9 (LXX) \\
\hline & & $\begin{array}{l}\text { to take possession } \\
\text { of the land. }\end{array}$ & $\begin{array}{l}\text { to take possession } \\
\text { of the land. }\end{array}$ \\
\hline & $\begin{array}{l}\text { 29. And Israel } \\
\text { served } \\
\text { the Lord all the } \\
\text { days of Joshua and } \\
\text { all the days of the } \\
\text { elders who outlived } \\
\text { Joshua and who } \\
\text { had seen all the } \\
\text { work that } \\
\text { the Lord did for } \\
\text { Israel. }\end{array}$ & $\begin{array}{l}\text { 7. And the people } \\
\text { served } \\
\text { the Lord all the } \\
\text { days of Joshua and } \\
\text { all the days of the } \\
\text { elders who outlived } \\
\text { Joshua, } \\
\text { who had seen all } \\
\text { the great work that } \\
\text { YHWH did for } \\
\text { Israel. }\end{array}$ & $\begin{array}{l}\text { 7. And the people } \\
\text { served } \\
\text { the Lord all the } \\
\text { days of Joshua and } \\
\text { all the days of the } \\
\text { elders, who out- } \\
\text { lived Joshua, } \\
\text { who had known all } \\
\text { the great work that } \\
\text { the Lord did for } \\
\text { Israel. }\end{array}$ \\
\hline $\begin{array}{l}\text { 29. And it hap- } \\
\text { pened after these }\end{array}$ & $\begin{array}{l}\text { 30. After these } \\
\text { things }\end{array}$ & 8. & 8. \\
\hline $\begin{array}{l}\text { things: } \\
\text { that Joshua son of } \\
\text { Nun, } \\
\text { servant of YHWH, } \\
\text { died at one hun- } \\
\text { dred and ten years. }\end{array}$ & $\begin{array}{l}\text { Joshua son of } \\
\text { Nun, } \\
\text { servant of the Lord, } \\
\text { died at one hun- } \\
\text { dred and ten years } \\
\text { old. }\end{array}$ & $\begin{array}{l}\text { And Joshua son of } \\
\text { Nun, } \\
\text { servant of YHWH, } \\
\text { died at one hun- } \\
\text { dred and ten years. }\end{array}$ & $\begin{array}{l}\text { And Joshua son of } \\
\text { Nun, } \\
\text { servant of the Lord, } \\
\text { died at one hun- } \\
\text { dred and ten years. }\end{array}$ \\
\hline $\begin{array}{l}\text { 30. And they buried } \\
\text { him at the borders } \\
\text { of his inheritance } \\
\text { in Timnath-serah } \\
\text { in Mount Ephraim, } \\
\text { north of Mount } \\
\text { Gaash. }\end{array}$ & $\begin{array}{l}\text { 31. And they buried } \\
\text { him at the borders } \\
\text { of his inheritance } \\
\text { in Timnath-serah } \\
\text { in Mount Ephraim, } \\
\text { north of Mount } \\
\text { Gaas. }\end{array}$ & $\begin{array}{l}\text { 9. And they buried } \\
\text { him at the borders } \\
\text { of his inheritance } \\
\text { in Timnath-heres } \\
\text { in Mount Ephraim, } \\
\text { north of Mount } \\
\text { Gaash. }\end{array}$ & $\begin{array}{l}\text { 9. And they buried } \\
\text { him at the borders } \\
\text { of his inheritance } \\
\text { in Timnath-heres } \\
\text { in Mount Ephraim, } \\
\text { north of Mount } \\
\text { Gaas. }\end{array}$ \\
\hline
\end{tabular}

31a. There they put with him, into the tomb in which they buried him, the flint knives with which he circumcised the sons of Israel in Galgala, when he led them out of Egypt, as the Lord instructed them, and there they are until this very day. 
Josh 24:28-31 (MT) Josh 24:28-31 (LXX) Judg 2:6-9 (MT) Judg 2:6-9 (LXX)

31. And Israel

served

the Lord all the

days of Joshua and

all the days of the

elders who outlived

Joshua and who

had known all the

work that

the Lord did for

Israel.

\subsection{Different sequence in MT Joshua}

The first revealing difference between the four versions is the different sequence in MT Joshua. The last verse in MT Joshua (28:31) is situated after Joshua's death and burial. By contrast, in all the other witnesses it is situated before his death. In terms of content, MT Josh 24:31 highlights the people's fidelity to YHWH during Joshua's lifetime and during the lifetime of the elders that outlived Joshua and knew YHWH's deeds. In a sense, MT Josh 24:31 assumes that the days of Joshua will end, but it does not require that Joshua's death be reported right before the verse. ${ }^{15}$ Moreover, the death and burial report is formulaic (cf. Gen 35:28-29, 50:26, Deut 34:5-7) and is not dependent upon MT Josh 24:31. The death and burial verses (MT Josh 24:29-30) and the verse on the fidelity of the people (MT Josh 24:31) are therefore not dependent on each other which explains why their mutual order can be different in various textual versions.

Overall, the fidelity notice (MT Josh 24:31, LXX Josh 24:29, Judg 2:7) is better suited to the context of Joshua 24 than Judges 2, and it probably originated there. The main structure of Joshua 24 is a dialogue between Joshua and the people in which the question of loyalty to YHWH is central. This dialogue ends with a triple promise by the people to serve only $\mathrm{YHWH}$ (vv. 18-20, 21, and 24). In verse 24:31 (MT), the realization of this promise is narrated. That the verse was originally written for Joshua 24 is corroborated

15 Contra Rösel, "Die Überleitungen," 344. The reference to the days of the elders who outlived Joshua can be read as an anticipatory statement. The emphasis of "the elders who outlived Joshua" is not so much about the death of Joshua; rather, it binds the fidelity statement together with the mention of the elders at the beginning of the chapter $(24: 1)$. 
by vocabulary and themes similar to other verses in Joshua $24 .{ }^{16}$ The parallel verse Judg 2:7, however, is in contradiction with its context and especially the preceding verses, e. g. Judg 2:2 that recalls the infidelity of the Israelites. Moreover, the context in Judges is not occupied with the "days of Joshua" as verse Judg 2:7 would imply. For instance, Judg 2:1-5 deals with the angel of YHWH and his message. Therefore, Judg 2:7 forms a back-reference to the themes in Joshua 24 and does not originally belong to Judges $2 .{ }^{17}$

Is the earlier location for MT verse 24:31 before or after Joshua's death has been narrated? The main narrative of Joshua's speech and his dialogue with the people is located in verses 24:1-28, while verses 29-33 deal with the burials of three great men (Joshua, Joseph, and Eleazar). MT verse 24:31, emphasizing the realization of the people's fidelity to YHWH, is more connected with the former entity. Therefore MT Josh 24:31 can be seen as a realization and conclusion to the dialogue in $24: 1-28$ created by the original author or a redactor. ${ }^{18}$ In LXX Joshua 24 this function is preserved since the verse directly follows the dialogue. The order preserved in LXX Joshua and both versions of Judges is then probably earlier and the sequence in MT Joshua is secondary. ${ }^{19}$ The argument for the secondary status of the MT sequence is strengthened by a comparison with the sequence of events in Deuteronomy 34. There, the death of Moses is narrated. The sequence of events is similar to that of MT Joshua 24. First, Moses dies and is buried (Deut 34:5-6, Josh 24:29-30) and then the fidelity of the Israelites after the death of Moses is narrated (Deut 34:9, MT Josh 24:31). Thus it seems that the order in MT Joshua reflects harmonization with the death account of Moses. The sequence may have been adjusted in order to make the ending of Joshua

16 The main characters of MT Josh 24:31 are taken from Josh 24 (Joshua, the people, and YHWH). Similar expressions include: to serve YHWH (vv. 24:14-24), the elders (24:1), and a reference to the deeds that YHWH did for Israel (24:17).

17 Contra A. G. Auld, Joshua Retold: Synoptic Perspectives (Bloomsbury: T\&T Clark, 2005), $82-83$.

18 The nature of the verse as a positive conclusion to the dialogue is also reflected in the comments of M.H. Woudstra, The Book of Joshua (Grand Rapids: Eerdmans, 1981), 360.

19 Thus also A. Schulz, Das Buch Josue (HSAT 2/3, Bonn: Peter Hanstein Verlag, 1924), 76; R. G. Boling \& G. E. Wright, Joshua. A New Translation with Introduction and Commentary (New Haven: Yale University Press, 1982), 541; Rofé, The End, 22 and Auld, Joshua Retold, 81. Contra, for example, M. O’Brien, The Deuteronomistic History Hypothesis: A Reassessment (Göttingen: Vandenhoeck \& Ruprecht, 1989), 81 who argues that LXX Josh 24 secondarily changes the sequence due to the sequence in Judg 2:6-7. His argument relies on the literary critical assumption that in the original text of the DtrH there was no assembly or dismissal but only verses MT Josh 24:29-31. This does not seem probable since MT Josh 24:31 probably owes its content to Josh 24:1-28. 
24 correspond more closely with Deuteronomy 34 . This could be seen as an attempt to derive more authority from the figure of Moses. ${ }^{20}$

Furthermore, the sequential difference is probably connected to the variant beginnings of the next verse that reports the death of Joshua (MT Josh 24:29, LXX Josh 24:30, Judg 2:8). Contrary to the death report in Judges, MT and LXX Joshua have an introductory formula ("and it happened after these things") before the death is narrated. ${ }^{21}$ Such an introductory formula might be an indication that the death and burial account has been secondarily added to the chapter. ${ }^{22}$ The death account in Joshua preserves this redactional link. The lack of the introduction in Judges can be explained as an intentional omission due to a new context in Judges. In the context of Joshua, the introduction was needed to link the dialogue part (LXX 24:1-29) with the death and burial notices (LXX 24:30 ff.). In Judges, this link was no longer needed. Therefore, Joshua preserves the roughness that may have been created by earlier editing while Judges smoothens it out.

The most plausible development here is as following. ${ }^{23}$ The earliest ending for the covenant scene is preserved in LXX Josh 24:28-29. At some point, the death and burial notice of Joshua (LXX Josh 24:30-31a) was added to the covenant scene. A sign of this addition is preserved in both the LXX and MT Joshua ("and it happened after these things"). Judges 2:6-9 secondarily adapted LXX Josh 24:28-31 into a new context in which the verse reporting the fidelity of the people was contrasted with the infidelity of the new generations (Judg 2:10). ${ }^{24}$ Due to this dependence both LXX Josh 24:28-31 and Judg 2:6-9 preserve the earliest sequence of the pericope. Furthermore,

20 For the depiction of Joshua as a second Moses in Joshua 24, see T. Römer, "Book-Endings in Joshua and the Question of the So-Called Deuteronomistic History," in Raising Up a Faithful Exegete (ed. K. L. Noll and B. Schramm; Winona Lake: Eisenbrauns, 2010), 97. Rofé, The End, 23 argues that the relocation was made since a scribe perceived that the verse dealt primarily with the times of the elders after the death of Joshua. The sequence was thus made more logical.

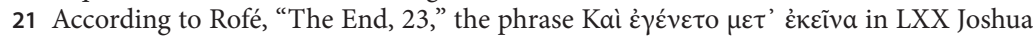
can not be a translation of the MT phrase wayhî 'ahărê hadděbārîm hä'èllê. Instead, the LXX Vorlage would have read wayhî' ahărê.

22 As argued by, for example, H. N. Rösel, Joshua. Historical Commentary on the Old Testament (Leuven: Peeters, 2011), 376.

23 Much has been written on the problem of the earlier sequence of these events. At this point, unfortunately, I do not have room to interact more with these several models. The strength of my proposition is that it explains all of the available evidence, also that of the LXX, in a relatively simple manner (Occam's razor). My proposition does not require resorting to complex literary and redaction critical explanations or assumptions on the relationship of the books of Joshua and Judges.

24 That Judg 2:6-9 is a later adaptation is also seen in several secondary textual developments that will are analyzed below. 
MT Josh 24:28-31 reflects a secondary reworking of the sequence of events. This reworking might have been prompted by an editorial motive to better integrate the added death and burial notice(s) with the verse reporting the fidelity of the Israelites after the "days of Joshua". It might have also been influenced by a harmonization with the death and burial account of Moses. This is an intriguing option since, as we see later, there are also other editorial developments behind MT Josh 24 that aim at emphasizing the role of Moses.

\subsection{Omission of LXX Josh 24:31a}

The other notable variant in these verses is the long plus in LXX Joshua that is not present anywhere else. ${ }^{25}$ That the Greek translator would have created such a verse goes against what we have concluded about the nature of the translation. Even though the translator possessed some degree of freedom, he would not have conjured up such a long addition as a part of the translation process. It is also not plausible that the plus was lost due to a scribal lapse since a similar plus missing in the MT also exists in LXX Josh 21:42d: "And Iesous took the flint knives with which he circumcised the sons of Israel born on the way in the wilderness, and he put them in Thamnasarach" (NETS). We have, then, two possible explanations. Either both of these plusses are secondary additions made to the Hebrew Vorlage of the LXX or they are earlier material intentionally omitted in the proto-MT editing.

First we should explore whether this verse could be a secondary addition made to the Hebrew Vorlage of the LXX. There is some appeal to this argument. Hartmut Rösel has noted that the presumably added verse is connected with Josh 5:4-5 which narrates the circumcision performed by Joshua. In addition, Rösel notes that the beginning of the LXX addition in

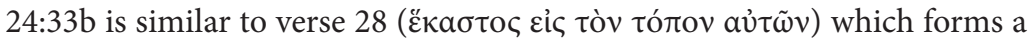
resumptive repetition, providing additional support for the assumed lateness of the plusses between them. ${ }^{26}$ The problem with this argument is, however, that it presumes that all the plusses in the LXX verses 31-33 can be explained together. In my opinion, this Wiederaufnahme would only support the secondary nature of all or some of the plusses in verse 33. It does not prove the secondary nature of verse $31 \mathrm{a}$.

25 The plus is also probably somehow connected with the longer ending in LXX Josh 24:33a-b. In this study, I will exclude the analysis of those verses and focus on 31a. The analysis of this plus is also interesting in its own right since it is usually explained together with the longer ending (e.g. Rösel, Die Überleitungen; and Rofé, The End).

26 Rösel, Die Überleitungen, 349. 
If LXX verse 31a were a secondary addition, the motives for such an expansion would be hard to imagine. Arnold Ehrlich suggested in his early commentary that this could be an addition made by a Hellenistic Jew (the LXX translator) who found the idea of Joshua circumcising the people embarrassing and wanted to make sure that the "grotesque rite" was buried with Joshua. ${ }^{27}$ This is a highly conjectural statement. A more plausible motive could be the desire to indicate the final repository of the flint knives with which an important covenantal act was performed. In verse 32 , the burial of Joseph's bones was reported and that could have given the spark for an editor to include the flint knives in Joshua's burial. While this is a possible explanation, the theological peculiarity and the connections of this verse with earlier material in LXX Joshua opens up a much more persuasive explanation.

The theological peculiarity of this material lies in two claims that it makes: that the Israelites buried the same flint knives with Joshua with which he once circumcised them (Josh 5:2-9) and that it was primarily Joshua, not Moses, who lead the Israelites out of Egypt. ${ }^{28}$ The first point concerning the burying of the flint knives implies that these objects were revered. They were perceived as religious relics. ${ }^{29}$ Whereas Rösel claims that there is nothing novel in this plus in relation to Josh $5,{ }^{30}$ it seems apparent that the importance put on material objects is new here. This point alone would be enough for a late editor to omit this plus since the reverence of an object could be perceived as idolatry by later editors. There might, however, also be a more thorough editing process behind the plus which can be seen in the earlier material in LXX Joshua.

Josh. 5:4-5, $9(M T)$

Josh. 5:4-5, 9 (LXX)

44

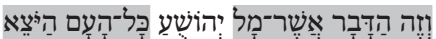

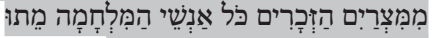

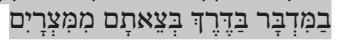

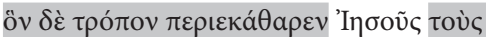

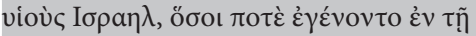

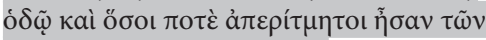

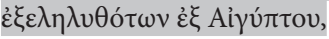

55

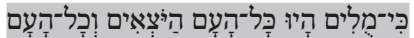

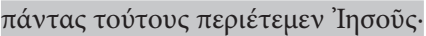

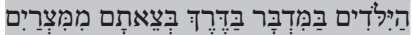

לאיאָלוּו

27 Arnold Ehrlich, Randglossen zur Hebräischen Bibel. Textkritisches, Sprachliches und Sachliches. Dritter Band (Leipzig: J. C. Hinrichs, 1910), 66. This explanation is taken up by Rösel, Joshua, 377.

28 These theological peculiarities were also noted by Rofé, The End, 23-24.

29 Thus also Rofé, The End, 24.

30 Rösel, Die Überleitungen, 349. 
Josh. 5:4-5, 9 (LXX)

\begin{tabular}{|c|c|}
\hline & \\
\hline 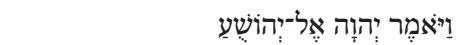 & 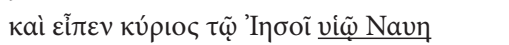 \\
\hline הַיוֹם גַּלוֹתִתי & 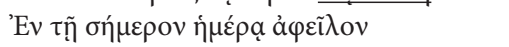 \\
\hline 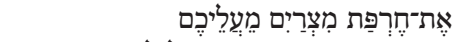 & 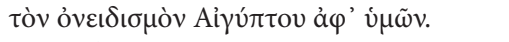 \\
\hline 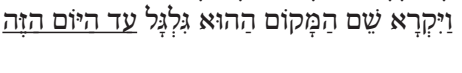 & 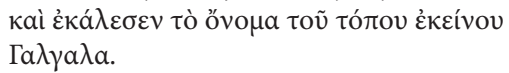 \\
\hline
\end{tabular}

Josh. 5:4-5, 9 (MT)

Josh. 5:4-5, 9 (LXX)

4. This is why Joshua circumcised them: all the males of the people who came out of Egypt, all the warriors, had died on 4. And how Joshua purified the sons of Israel: as many as were born on the way and as many as were uncircumcised of those who had come out of Egypt,

the way through the wilderness after they had come out of Egypt.

5. Although all the people who came out had been circumcised, yet all the people 5. all these Joshua circumcised. born on the journey through the wilderness after they had come out of Egypt had not been circumcised. $\ldots$

9. And YHWH said to Joshua,

"Today I have taken away the disgrace of Egypt from you." And he called the name of that place Gilgal to this day.

And the Lord said to Joshua son of Nun: "Today I have taken away the disgrace of Egypt from you." And he called the name of that place Galgala.

In the MT in relation to the LXX, Josh 5:4-5 differs almost completely. One of the witnesses probably reflects extensive rewriting. ${ }^{31}$ The most notable difference is that LXX Joshua claims that many of the Israelites coming out of Egypt were uncircumcised. MT Joshua, however, specifies extensively that everyone coming out of Egypt was circumcised and Joshua only had to circumcise those who were born in the wilderness. The reading in MT Joshua is problematic since the circumcision performed by Joshua is said to have removed the "disgrace of Egypt" (Josh 5:9, 'et herppat miṣrayim) and there would be no disgrace left if everyone in Egypt was circumcised. ${ }^{32}$

31 There are many differences between the circumcision accounts (Josh 5:2-9). I will focus on these two verses and their major thematic difference since it has an impact on the plus in LXX Josh 24:31.

32 M. van der Meer, Formation, 311-315 correctly points out that multiple interpretations have been given for the expression "disgrace of Egypt." From this, it does not follow that the phrase "does not refer to the circumcision mentioned in the preceding verses 5:2-9” (M. Van der Meer, Formation, 314). In other words, that the expression might have multiple meanings does not rule out the most obvious interpretation emerging from the current context. 
An expansive rewriting in the proto-MT phase of 5:4-5 best explains the differences. ${ }^{33}$ Such a rewriting could have been triggered by the worrying notion in the earlier text, preserved in the LXX, that there was uncircumcised people among the Israelites coming out of Egypt. An editor wanted to omit this and "correct" the reasons for the circumcision performed by Joshua. When YHWH had so greatly helped the Israelites in getting out of Egypt, surely they would have had to have been loyal in circumcision. Thus, only those born in the wilderness needed to be circumcised. A second motivation for the rewriting behind the MT was the need to emphasize that the generation that came out of Egypt died (MT Josh 5:4) and that it was a new generation (MT Josh 5:5) that went to conquer the promised land. This is a harmonization towards Deut 1:34-46 in which a punishment was given that the exodus generation would not see the promised land. The editor behind the MT reading sharpened the difference between two generations in Josh 5:4-5 in order to make sure that the punishment given in Deuteronomy was realized. As Richard Nelson notes, the revised text (MT) "sharpens the differentiation between the old disobedient generation - and the new obedient generation". ${ }^{34}$ The claim that the earliest version is preserved in LXX Joshua is also corroborated by it being the shorter text (lectio brevior). ${ }^{35}$

Josh. 21:42 (LXX)

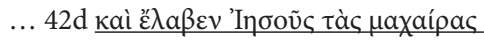

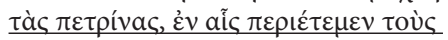

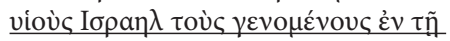

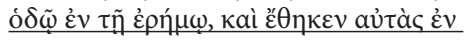

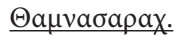

... 42d And Joshua took the flint knives with which he circumcised the sons of Israel born on the way in the wilderness, and he put them in Timnat-serah.

33 Thus, also S. Holmes, Joshua. The Hebrew and Greek Texts (Cambridge: Cambridge University Press, 1914), 9-10, 28-30; and R. D. Nelson, Joshua. The Old Testament Library (Louisville: Westminster John Knox Press, 1997), 71-83.

34 R. D. Nelson, Joshua, 77.

35 K. Bieberstein, Josua - Jordan - Jericho. Archäologie, Geschichte und Theologie der Landnahme-erzählungen Josua 1-6 (Göttingen: Vandenhoeck \& Ruprecht, 1995), 198-206 argued that the LXX is secondary and the differences are due to the interpretative actions of the Greek translator who wanted to harmonize the passage with the Pentateuch. There is no room here to give a detailed counterargument but overall the assumed references to the Pentateuch are, in my opinion, too vague to override the well-documented assumption that the translator would not take such liberties. 
In LXX Joshua 21:42, there are several plusses not present in the MT. The last plus (42d) pertains to LXX Josh 24:31a and is therefore interesting for us. ${ }^{36}$ An omission of both of these plusses in the MT could well be connected to the rewriting that took place in the proto-MT editing of 5:4-5. The editor who wanted to delete the presence of uncircumcised Israelites coming out of Egypt would have wanted to remove these verses since they commemorate the flint knives with which the Israelites were "purified" ( $\pi \varepsilon \rho ı a \theta a i \rho \omega$, LXX Josh 5:4). ${ }^{37}$ The editor who was disturbed by the notion that the Israelites did not universally practice circumcision in Egypt wanted to omit any recollections of that. ${ }^{38}$ Thus, an omission of $21: 42 \mathrm{~d}$ and 24:31a downplayed the importance of the flint knives and the memory of the uncircumcised Israelites in Egypt.

In the plus LXX Josh 24:31a, the second offensive issue is that it was actually Joshua who brought the people out of Egypt and that, for this exodus, he was given the instructions by YHWH. There is no mention of Moses here. What makes it even more significant is that the LXX is missing the reference to Moses present in MT Joshua 24:5 (wā'ešlah 'et mōšê wĕ'et 'ahărōn). It is thus possible that the same editor was responsible for omitting verse 31 a from the proto-MT text and adding the reference to Moses in verse 5 in order to introduce Moses into the exodus. In the LXX version of Joshua 24, there are numerous references to the exodus but no references to Moses. It seems, then, that we might have here a remnant of a version of the exodus tradition that emphasizes Joshua's role in leading the people out of Egypt. This verse could, interestingly, have an impact on the reconstruction of the evolution of the exodus traditions. At least, the portrayal of Joshua as a leader of the exodus was softened by introducing Moses into verse 5 and removing verse $31 \mathrm{a}$. In this way, the proto-MT editor was interested in introducing the authority of Moses into the chapter. ${ }^{39}$

36 Already Holmes, Joshua, 74 noted that this plus "stands or falls" with 24:31a.

37 The Greek $\pi \varepsilon \rho \iota \kappa a \theta a i ́ \rho \omega$ "to purify" is obviously not a standard equivalent for môl "to circumcise." The translation choice is one of the interpretive initiatives that the OG translator takes in translating Josh 5:2-12. For more on these, see M. van der Meer, Formation, 334-416. The translation of Josh 5:2-12 is one example of the freedoms that the translator could take in choosing varying Greek equivalents in respect to his Hebrew Vorlage. The freedom in producing contextualized Greek does not, however, mean that the whole rewriting reflected in Josh 5:2-12 could be attributed to the translator as Van der Meer argues in his treatment.

38 Thus also Holmes, Joshua, 9-10.

39 Thus also Rofé, The End, 23-24. A subtle strenghtening of the role of Moses might, in fact, be a trait of the proto-MT editing in the book of Joshua as a whole. There are six instances where Moses is secondarily added to the MT and he is missing in the earlier 
Even if one does not accept the connections drawn here between chapter 5 and the plus in verse 24:31a, the theological peculiarities alone make it much more likely that verse $31 \mathrm{a}$ is an omission in the proto-MT tradition and not a late secondary addition. It is simply not plausible that a Hebrew editor would have added such a polemic verse in a late context where the position of Moses and the authority of the Pentateuch had been firmly established. Hence, LXX Joshua preserves an earlier verse linked with the death and burial of Joshua while MT Joshua omits the verse out of theological consideration. The absence of the verse in Judges is understandable since Judg 2:6-9 represents a later adaptation of the pericope whose aim is to reverse the theme of the fidelity of the Israelites. The burial of the flint knives or Joseph's bones is not as such of interest in this new context. ${ }^{40}$

\subsection{Other minor variants}

Many minor variants corroborate the assumption that LXX Josh 24:28-31 generally preserves the earliest text. In the first verse, Joshua sends the people away. While the first sentence is similar in all readings, there are considerable differences in the latter part that reports the people going back to their inheritance or place. ${ }^{41}$ Two of these reveal the secondary nature of Judg 2:6. First, in Joshua the people are referred to only as 'î̌ while Judges gives as a plus a more specific bĕnê yišrā'ēl which should be seen as a later addition harmonizing the text with the preceding verse in the context of Judges (Judg 2:4). ${ }^{42}$ Second, Judg 2:6 includes a report that the Israelites went to take possession of the land ('et hā'āreș lārešet). This expression might well be a

OG readings (Josh $1: 14 ; 4: 10 ; 13: 33 ; 14: 2,3 ; 24: 5)$. Furthermore, the title of Moses as "servant of YHWH" is secondarily added in four verses in the MT (Josh 1:1, 15; 12:6; 22:4).

40 We do not know whether the editor of Judges knew LXX Josh 24:31a or the other burial notices (Josh 24:31-33) when he adapted LXX Josh 24:28-31 into his new composition. On the one hand, since he follows the sequence of LXX Josh 24:28-31 it is possible that he was aware of the verse dealing with the flint knives. On the other hand, the verse might have been omitted in such an early stage that the Vorlage of the editor of Judges did not have it. In any case, the themes introduced in Judg 2:10 was the reason for including verses from the end of Josh 24 in the first place.

41 LXX Josh 24:28 might reflect a different Hebrew Vorlage in reading "each to his place." See Koopmans, Joshua 24, 263-264.

42 It would be harder to explain why běnê yišrā'ēl would have been omitted in Joshua. There are no possible stylistic reasons or ideological motives that would cause such an omission. 
late Deuteronomically inspired insertion. ${ }^{43}$ The shorter version preserved in Joshua would certainly be good soil for such an addition. ${ }^{44}$

In the second verse (LXX Josh 24:29, MT Josh 24:31, Judg 2:7), there is variation between the verbs $r^{\prime} h$ and $y d^{c}$. The Vorlage of LXX Joshua probably reflects $r$ ' $h$ since the verb $y d$ ' is never translated with ó áw in Joshua. ${ }^{45}$ MT Judges also uses $r^{\prime} h$, while MT Joshua and LXX Judges employ $y d^{c}$ (LXX Judges $\left.\varepsilon^{\prime} \gamma \nu \omega \sigma \alpha \nu\right)$. It is not easy to decide which verb is earlier since both can be used synonymously. Still, verb $r^{\prime} h$ might well be the more original because the elders concerned are perceived as eyewitnesses to the deeds of YHWH. Verb $y d^{c}$ would then be a later change to a verb with a wider semantic field that would include even people who had not seen the deeds of YHWH but knew of them. This hypothesis would strenghten the conclusions that LXX Joshua holds the more original text of this verse that has been further edited in MT Joshua and - in this case - LXX Judges. ${ }^{46}$ This conclusion should, however, be viewed with caution as these verbs can be used quite synonymously.

There is also, in the verse reporting the fidelity in Judg 2:7, the plus haggādōl reflected by both the LXX and the MT. It seems to be a late addition as it interrupts the fluent syntax that can be observed in Joshua. The function of this addition is to further emphasize the mightiness of YHWH's works. It is, as Rösel puts it, "eine sekundäre Verstärkung." 47 Once again,

43 The verb yrš occurs 34 times in Deuteronomy. Compared to the second largest occurrence rate of 8 in Joshua, the concept of "taking possession of the land" is clearly linked with Deuteronomistic ideology. See also G. N. Knoppers, "Establishing the Rule of Law? The Composition Num 33,50-56 and the Relationship Among the Pentateuch, the Hexateuch and the Deuteronomistic History," in Das Deuteronomium Zwischen Pentateuch und Deuteronomistischen Geschichtswerk (ed. R. Achenbach and E. Otto; Göttingen: Vandenhoeck \& Ruprecht, 2005), 147-148. This expression is also seen as a late addition by Rösel, Die Überleitungen, 344 .

44 Otherwise, one would have to argue why MT and LXX Joshua omit this expression. A parablepsis is not possible here. Thus, the omission would be intentional. Auld, Joshua Retold, 82, argues that Joshua indeed omits this phrase, which belongs to the more original reading. According to Auld, the omission is made because the book of Joshua aims to give the impression that the settlement of the land was completed before Joshua's death. This argument could, however, also be used in the other direction: maybe the editor of Judges added the notion in order to highlight that the taking possession of the land was not yet completed.

45 The most common equivalent for $y d^{c}$ in Joshua is $\gamma ı v \omega \sigma \kappa \omega$.

46 However, OG Judg 2:6 might have also read "had seen" since the Old Latin manuscript $\mathrm{La}^{100}$ reads viderunt. "Had known" would then be a secondary development in the Greek text of Judges. That viderunt might reflect a different Greek Vorlage of OL is corroborated by the observation that this is the only place in OL Judges where video is used for $\gamma \iota v \omega ́ \sigma \kappa \omega$.

47 Rösel, Die Überleitungen, 344. 
the addition further strengthens the argument that the version in Judges is secondary to Joshua. ${ }^{48}$

\subsection{Text-critical conclusions}

The textual growth of the death and burial of Joshua visible in documented evidence can be summarized as follows. The earliest extant version is mostly preserved in LXX Joshua. This version is generally the shortest but ends with one large plus that contains material that reflects thoughts that were deleted by a later editor. The version preserved by MT Joshua is the result of expansions, a relocation, and an omission from this shorter version. The version present in MT Judges, in turn, is a later adaptation to a new context and it has emerged mainly through expansive harmonization. MT Judges agrees with LXX Joshua in its arrangement and in some other minor details against MT Joshua. Hence, the editor of Judges probably used a version similar to the Hebrew Vorlage of LXX Joshua as his source text. Therefore, the account in MT Judges preserves textual features that are earlier than MT Joshua, most prominently the earlier sequence of the verses. Moreover, LXX Judges translates the expanded version in MT Judges almost word for word and should not be regarded as a different literary version.

\section{Repercussions for literary and redaction criticism}

In the narrative concerning Joshua's death documented evidence exists for the latest literary growth of these four verses. It can be concluded with a good degree of probability that LXX Joshua preserves the earliest text behind this textual growth. Therefore any literary critic wanting to reconstruct the compositional stages of the pericope may not neglect the LXX. Literary and redaction criticism based only on the MT versions is problematic. This point has been rightfully stressed by several scholars working with different books

48 I would not read too much into the various names of the burial place. Where MT Joshua reads timnat-serah, MT Judges has timnat-heres. This could be a simple metathesis either way. In LXX Joshua, B reads $\theta \alpha \mu v a \theta \alpha \sigma \alpha \chi \alpha \rho \alpha$ and A $\theta \alpha \mu v \alpha \sigma \alpha \chi \alpha \rho$. Whichever is the correct OG reading, it still probably reflects the Hebrew timnat-serah since in Judges timnat-heres is transcribed with either $\theta \alpha \mu v \alpha \theta \alpha \rho \varepsilon \varsigma$ (B) or $\theta \alpha \mu v a \theta \alpha \rho \varepsilon \omega \varsigma$ (A). If the change was intentional, the more original reading would probably be timnat-heres since it can be perceived as more offensive. This, however, is speculative as the offensiveness of this place name is not that obvious. Thus either one could be the more original reading. 
of the Hebrew Bible. ${ }^{49}$ In the case of the book of Joshua, Kristin De Troyer, for one, has argued for the text-critical value of LXX Joshua and articulated the need for taking the "results of a renewed textual criticism" into account in literary and redaction criticism. ${ }^{50}$

Many important texts remain understudied in the light of this growing demand for crossing arbitrary methodological boundaries. Joshua 24 belongs to one of the most important, complex, and contested texts in the historical books of the Hebrew Bible. At the seam of the "Hexateuch" and the Former Prophets it takes a differing role in several different compositional theories. Thus it seems that a fresh analysis of LXX Joshua 24 and its impact on literary and redaction criticism is in order. Since we have, in this study, analyzed only four verses of Joshua 24 a complete discussion of the literary development of Joshua 24 is not possible. ${ }^{51}$ Accordingly, I will limit the remaining discussion to examining some repercussion of the text-critical evidence on literary and redaction criticism of Joshua 24.

When evaluating literary and redaction critical models in the light of textual evidence, my main argument is: textual criticism sets boundaries for what can be argued in literary and redaction criticism. This argument follows logically if one accepts the text-critical conclusion that the differences between LXX and MT represent the latest stages in the literary growth of the book of Joshua. Therefore, textual criticism overrules some possibilities for what can be argued in terms of the compositional history of Joshua. At least three current compositional positions are overruled or in need of adjustments in the light of the textual evidence analyzed in this study.

49 For example, Edenburg and Pakkala write that "it is necessary to bring the text-critical evidence to the fore in the discussion about redactions" in C. Edenburgh and J. Pakkala, "Is Samuel among the Deuteronomists?" in Is Samuel among the Deuteronomists? Current Views on the Place of Samuel in a Deuteronomistic History (ed. C. Edenburgh and J. Pakkala; Atlanta: SBL, 2013), 12-13. The idea of integrating documented or "empirical" evidence from variant versions witnessing to the same text to the discussion concerning the editorial processes of the Hebrew Bible was greatly advanced by J.H. Tigay (ed.), Empirical Models for Biblical Criticism (Philadelphia: University of Pennsylvania Press, 1985). This line of inquiry has been further pursued by, for example, D. Carr, The Formation of the Hebrew Bible: A New Reconstruction (Oxford: Oxford University Press, 2011); and R. Müller et al., Evidence of Editing: Growth and Change of Texts in the Hebrew Bible (Atlanta: SBL, 2014). Evaluating and refining literary criticism with the help of documented evidence is also one of the aims of the research team Literary Criticism in the Light of Documented Evidence working in the Helsinki Centre of Excellence Changes in Sacred Texts and Traditions (www.cstt.fi).

50 K. De Troyer, Rewriting the Sacred Texts: What the Old Greek Tells Us about the Literary Growth of the Bible (Leiden: Brill, 2003), 127-128. See also K. De Troyer, "Reconstructing the Older Hebrew Text of the Book of Joshua," Text 26 (2013): 1-33.

51 Such an analysis will be available in my upcoming dissertation. See footnote 3. 
First, one of the main questions of literary criticism is the unity or disunity of a particular text. Recently several scholars have put forth models arguing that Joshua 24 is, for the most part, a unified text in which different literary strata should not be reconstructed. In these models, Joshua 24 is often regarded as a late postexilic and post-Dtr literary composition. The important work of Erhard Blum should be mentioned. Blum has suggested that Joshua 24 is the work of a Hexateuchal redactor. This redactor composed the chapter as a concluding statement for a late Hexateuch connecting the books from Genesis to Joshua. ${ }^{52}$ Also John Van Seters has argued for the basic unity of Joshua 24 and regarded it as the work of a post-Dtr author. Van Seters has identified this author as the Yahwist who he has postulated in several other instances. ${ }^{53}$ The recent emphasis on the assumed unity of Joshua 24 is echoed in a citation from Thomas Römer: "There is no need for or evidence of reconstructing an older version of the account, which would not have contained this speech or would have contained only parts of it and which would have predated Joshua 23. Except for some glosses, there are very few indications of later insertions." 54

In my view, the repercussions for this discussion from the text-critical findings are, simply put: Documented evidence suggests that it is hard to regard Joshua 24 as a literary unity. At least two of the text-critical findings support this claim. Firstly, the omission of LXX Josh 24:31a in the proto-MT phase of editing should be seen as part of the diachronic development of Joshua 24. The omission was not an isolated or random deletion but part of a theologically motivated editorial intrusion. The effects of this editing can be seen at least in three different parts of the book of Joshua (Josh 5:2-9; 21:42; $24: 5,31)$. While this editorial intrusion should probably not be labeled as a redaction, it is a phase in the diachronic development of Joshua. Secondly, the uncertainty of the correct location of MT Josh 24:31 speaks against an assumption that the ending of Joshua 24 has been a literary unity from its beginnings. That the order in Josh 24:28-31 was rearranged in the course of the transmission history of Joshua 24 reveals that there has been consid-

52 E. Blum, Studien zur Komposition des Pentateuch (BZAW 189; Berlin: de Gruyter, 1990), 364-365; and "Der kompositionelle Knoten am Übergang von Josua zu Richter: Ein Entflechtungsvorschlag," in Deuteronomy and Deuteronomic Literature (ed. M. Vervenne and J. Lust; BEThl 132; Leuven: Peeters, 1997), 194-206.

53 J. Van Seters, "Joshua 24 and the Problem of Tradition in the Old Testament," in In the Shelter of Elyon: Essays on Ancient Palestinian Life and Literature in Honour of G. W. Ahlström (ed. W. B. Barrick and J. R. Spencer; JSOTSUP 31; Sheffield: JSOT Press, 1984), 139-158. Also S. D. Sperling, "Joshua 24 Re-examined," HUCA (1987): 119-136 regards Joshua 24 as a unity but gives it an early 8 th century dating.

54 T. Römer, "Book-Endings," 95-96. 
erable editorial activity at the end of the chapter. "Movable units" like MT Josh 24:31 attest to the complexity of the compositional processes at play and undermine assuming a literary unity. ${ }^{55}$

Several editorial phases need to be assumed already in order to explain all of the documented changes. Consequently, it is probable that such editing has taken place in Joshua 24, out of which documented evidence has not been preserved. ${ }^{56}$ We can assume that the manifold traces of editing preserved in the textual evidence of Joshua 24 are only the tip of the iceberg: The text has most probably undergone several stages of early literary development. ${ }^{57}$

To be sure, in this study I have not analyzed the textual variants in $24: 1-27$. It could be argued that the death and burial accounts at the end of Joshua 24 are later additions but vv. 1-27(28) are a literary unity. The question cannot be settled here but based on my own findings elsewhere and analyses by other scholars, ${ }^{58}$ it seems that already the text-critical situation in 24:1-27(28) points towards several stages of editing. The MT exhibits many secondary readings in relation to the LXX. Interestingly, several of these variants concentrate around verses which have often been evaluated in literary criticism as secondary. For example, it is probably not a coinci-

55 On "movable units" and their implications see, for example, T. Barrera, "Textual Criticism and the Composition History of Samuel. Connections Between Pericopes in 1 Samuel 1-4," Archaeology of the Books of Samuel. The Entangling of the Textual and Literary History (ed. P. Hugo and A. Schenker; Leiden: Brill, 2010), 261-264.

56 Regardless of the trend towards viewing Josh 24 as a literary unity many recent models give suggestions on these undocumented editorial processes. For example, R. Müller, Königtum und Gottesherrschaft: Untersuchungen zur alttestamentlichen Monarchiekritik (Tübingen: Mohr Siebeck, 2004), 251-254; U. Becker, "Endredaktionelle Kontextvernetzungen des Josua-Buches," in Die deuteronomistischen Geschichtswerke. Redaktions- und religionsgeschichtliche Perspektiven zur "Deuteronomismus"-Diskussion in Tora und Vorderen Propheten (ed. M. Witte, K. Schmid, D. Prechel and J.C. Gertz; BZAW 365, Berlin: de Gruyter, 2006), 139-162; Aurelius, "Zur Entstehung"; C. Levin, "On the Cohesion and Separation of Books within the Enneateuch," in Re-Reading the Scriptures: Essays on the Literary History of the Old Testament (Tübingen: Mohr Siebeck, 2013), 125-128. However, none of these models adequately integrate the LXX into their discussion.

57 In my opinion, the conclusion by Müller et al. is applicable also in the case of the compositional history of Joshua 24: “- - we can assume that these documented cases attest to merely a fraction of the actual changes that have taken place in the transmission - there are good reasons to assume that similar editorial processes took place during the earlier periods of the textual transmission that are largely undocumented by variant editions." R. Müller et al., Evidence of Editing, 9.

58 See, for example, the text-critical analyses in Holmes, Joshua, 78-80; Nielsen, Shechem: A Traditio-Historical Investigation (Copenhagen: G. E. C. Gad, 1955), 86-141 and Koopmans, Joshua 24, 241-270. 
dence that the secondary addition of wā'ôsî̀' 'et-'ăbôtêkem "and I took your fathers" (MT Josh 24:6) fits well together with the mention of the fathers by the sea (vv. 6-7) which has been regarded by some as a late addition to the historical summary. ${ }^{59}$ The short addition in MT Josh 24:6 might have been motivated by a desire to bind the earlier added mention of the fathers closer together with the rest of the text. In this way, the short addition revealed by text-critical evidence strengthens an earlier literary critical observation. Since many such instances are found in the text-critical evidence it overrules the possibilty that Josh $24: 1-27(28)$ is a literary unity.

Second, some models explaining the book seam between Joshua and Judges regard, contrary to the textual analysis in this study, the death account in Joshua secondary in relation to Judges. A common explanation within the paradigm of the Deuteronomistic history ( $\mathrm{DtrH})$ is that the original connection between Joshua and Judges continued from Josh 24:28 to Judg 2:7-10. Most recently this has been argued by Christoph Levin. ${ }^{60}$ According to Levin, short versions of the books of Joshua and Judges were once joined together. The text of this original DtrH ran from Josh 11:23b ("and the land had rest from war"), to the dismissal notice in $24: 28$, and further to the assumed original death notice in Judg 2:7-10. ${ }^{61}$ The next developmental stage was that Judg 2:1-5 was inserted between the conquest narrative and the death account of Joshua which resulted into the repetition of the original dismissal notice in Judg 2:6. ${ }^{62}$ Several minor additions were made to the book of Joshua while Joshua and Judges were still a unity. Among these was an early short form of the assembly at Shechem in Joshua $24 .{ }^{63} \mathrm{~A}$ decisive moment in the development of the text was when the books of Joshua and Judges were secondarily separated. After this book separation, the death of Joshua was secondarily repeated at the end of Joshua 24. Also the whole division of the land was added (Joshua 13-22) to the book of Joshua. Therefore, according to Levin, "half of today's book came into being after the separation". ${ }^{64}$

59 See, for example, the literary model by R. Müller, Königtum, 253.

60 The position has also been articulated by, for example, K. Latvus, God, Anger and Ideology: The Anger of God in Joshua and Judges in Relation to Deuteronomy and the Priestly Writings (JSOTSup 279, Sheffield: Sheffield Academic Press, 1998), 36. It goes back to the work of M. Noth, Überlieferungsgeschichtliche Studien: Erster Teil (Darmstadt: Wissenschaftliche Buchgesellschaft, 1963), 8-9.

61 C. Levin, "On the Cohesion," 126.

62 Ibid., 127.

63 Ibid., 128.

64 Ibid., 125-128. 
When this model of the Dtr book connection between Joshua and Judges is evaluated in the light of our textual analysis, some critical remarks arise. First of all, as a positive remark, the notion that the dismissal notice in Judg 2:6 was secondarily repeated from Josh 24:28 is confirmed. Our text-critical evaluation revealed that Judg 2:6 is in fact secondary in relation to Josh 24:28. However, the notion that the death and burial account in Judg 2:7-9 is earlier than the one in Josh 24:29-31 is questionable. ${ }^{65}$ When one neglects the LXX version of Josh 24:28-31, the account in Judg 2:7-9 might seem earlier since the sequence of events is better. Yet this sequence is already present in the earlier LXX version of Josh 24:29-31 and is secondarily followed by Judges. Since the sequence in MT Josh 24:29-31 is secondarily modified, it is understandable that ignoring LXX Josh 24 might lead one to conclude that the death account in Judg 2:7-9 is earlier. However, bringing the LXX into the fore of the comparison changes the picture. ${ }^{66}$

Also the absence of the verse reporting the burial of the flint knives has to be taken into account when evaluating the burial report in Judg 2:9. Its absence reveals that we are not dealing with the original burial account but with a selective later adaption. In order to be regarded as a compelling solution, a model of an early Dtr-connection between the books would have to account for the omitted verse preserved by the LXX. Theoretically, in the framework of Levin's model, the verse with the flint knives could be explained as a literary addition together with the addition of Joseph's bones to the burial account. ${ }^{67}$ These two verses, however, make such different textual connections that they would have to be explained as non-interdependent additions. The verse with the flint knives is closely connected with the innercompositional rewriting in Joshua while Joseph's bones refer back to Gen 50:25. Therefore if one accepts that the verse with the flint knives is earlier and has been secondarily omitted, one cannot accept the Dtr-connection between Joshua and Judges as such but the model needs to be modified.

65 Already without taking the LXX into account, within the different composition models of the DtrH, different solutions have been convincingly argued. For example, by M. O'Brien, The Deuteronomistic History Hypothesis: A Reassessment (Göttingen: Vandenhoeck \& Ruprecht, 1989), 81 argues for the originality of Josh 24:29-31 which was followed by Judg $2: 10$. Such a book connection would perhaps be more in line with the documented evidence.

66 In Levin's article, the only reference to text-critical evidence is given in the claim that the originality of Judg 2:7-10 can be "shown by details in the text" (C. Levin, "On the Cohesion," 125). In the footnote, reference is given to Auld, "Judges I". I have interacted with Auld's arguments in my textual analysis in some detail. See, for example, footnote 44.

67 C. Levin, “On the Cohesion,” 126, 132. 
Third, basically all of the models on the literary and redaction history of Joshua 24 and its relationship with Judges assume that the development of these texts took place only through additions and transpositions. ${ }^{68}$ The documented evidence analyzed in this study, however, has shown that also omissions and rewritings have taken place in the textual history of the book of Joshua. ${ }^{69}$ LXX Josh 24:31 revealed that a large section was probably omitted in the editing of the proto-MT version. In the circumcision account of Josh 5:2-9 a complete rewriting deleted older ideas from the text. If a literary analysis, aimed at finding out the earlier forms of these verses, was carried out based only on the MT versions of these texts, the omitted verse 31a and the shorter version of 5:2-9 could hardly be reconstructed. There are no traces left in the MT that would alert the literary critic that something has been omitted. Any plausible model on the literary development of Joshua 24 or the book seam of Joshua-Judges needs to explain these omissions. Moreover, when performing literary and redaction criticism on a complex text, such as Joshua 24, one should keep in mind that all of the textual material might simply not be available to the modern scholar. Things may have simply been dropped out in the course of editing. This, in turn, reminds us of the tentative nature of our diachronic models and cautions against extracting too many literary layers behind a particular text. ${ }^{70}$ While texts probably have developed in several layers, our methods for convincingly reconstructing these layers are limited.

\section{Discussion}

In this study, I have proposed one model on the textual growth of the account of Joshua's death and burial as preserved in Josh 24:28-31 and Judg $2: 6-9$. In many cases, the evaluation of textual changes is complicated and a

68 One exception on the book connection from Joshua to Judges is the model of A. Rofé, "The End of the Book of Joshua according to the Septuagint," Shmaton 2 (1977): 217-227 which assumes that the original material preserved in LXX Joshua has been lost in the MT.

69 The tendency in literary criticism to assume that the development of texts took place mainly through additions was recently criticized in J. Pakkala, God's Word Omitted: Omissions in the Transmission of the Hebrew Bible (Göttingen: Vandenhoeck \& Ruprecht, 2013).

70 For example, the identification of seven literary layers, as postulated in the model of R. Müller, Königtum, 253, seems too audacious. Even if the text had been developed in seven different layers, it is questionable whether we can recognize them anymore since also omissions and rewritings have taken place. 
number of uncertainty inevitably remains. Constructing a model of textual growth with the help of documented evidence, however, offers more objectivity in the field of textual studies, which is often accused of being overly subjective.

In the future, a careful analysis of Joshua 24 as a whole is needed taking into account the methodological aspects discussed in this study; that is, the analysis has to begin by evaluating variant textual versions which, in turn, sets boundaries and offers guidelines for what can be argued in literary and redaction criticism. In this context, the LXX has been and will be one of the most important textual witnesses. Nevertheless, in the study of the book of Joshua there are several other textual traditions that need to be integrated into the discussion. These include, for example, the witnesses among the Dead Sea Scrolls and perhaps also the Samaritan versions of the book of Joshua. ${ }^{71}$ An adequate model describing the diachronic development of Joshua - or any texts of the Hebrew Bible for that matter - explains the relationships of all of the textual witnesses and the peculiarities within individual witnesses. Such a model will undoubtedly not be a single line of development as it is so often imagined in traditional textual and literary criticism. It will rather be true to the textual plurality and complexity reflected already by documented evidence.

The analysis of Josh 24:28-31 and Judg 2:6-9 provides an excellent litmus test on different methodological approaches taken in the study of textual history. It reveals that methodological boundaries are often artificial. They can blind the scholar from seeing relevant evidence. In order to produce a reliable model on the textual history of Joshua 24, one needs to take all of the available evidence into account. Thomas Dozeman has appropriately noted that "The tendency among redaction critics is all too often to privilege or even limit research to the MT in determining the final form of Joshua or any book for that matter." 72 There are no good reasons for executing a literary or redaction critical analysis based only on the MT in the form we have it pre-

71 In this study, Qumran has not been mentioned since there are no witnesses to Josh 24:28-31 and Judg 2:6-9 among the Dead Sea Scrolls. Overall, the Joshua scrolls from Qumran attest to the textual plurality of Joshua in the late Second Temple Period. See, for example, F. C. Martínez, "Light on the Joshua Books from the Dead Sea Scrolls," in After Qumran: Old and Modern Editions of the Biblical Texts - The Historical Books (ed. H. Ausloos, B. Lemmeljin and J. T. Barrera; Leuven: Peeters, 2012), 145-159. For a brief overview of the Samaritan versions see, for example, I. Hjelm, The Samaritans and Early Judaism: A Literary Analysis (London: T\&T Clark, 2000), 98-99.

72 T. Dozeman, "Joshua as an Intertext," in Pentateuch, Hexateuch, or Enneateuch? Identifying Literary Works in Genesis Through Kings (Atlanta: SBL, 2011), 189-190. 
242 Ville Mäkipelto

served today. In some respects, this makes the work of a textual scholar more demanding. However, this is no reason for neglecting relevant evidence.

Ville Mäkipelto

Department of Biblical Studies

University of Helsinki

"Changes in Sacred Texts and Traditions"-

Finnish Academy's Centre of Excellence

Helsinki, PL 4, 00014

ville.makipelto@helsinki.fi 


\section{Hebrew Bible and Ancient Israel}

Edited by Gary N. Knoppers (Notre Dame IN), Oded Lipschits

(Tel Aviv), Carol A. Newsom (Atlanta GA), and Konrad Schmid (Zürich)

Redaction: Phillip Michael Lasater (Zürich)

Hebrew Bible and Ancient Israel publishes only invited articles. Submission of a paper will be held to imply that it contains original unpublished work and is not being submitted for publication elsewhere. All articles are refereed by specialists. Acceptance for publication will be given in writing. When an article is accepted for publication, the exclusive copyright is granted to Mohr Siebeck for publication in a print and an electronic version. Further information on this and the rights retained by the author can be found at www.mohr.de/hebai. No one may reproduce or distribute the entire journal or parts of it in a print or an electronic version without the publisher's permission. Please contact rights@mohr.de.

Please do not send any unsolicited review copies. The publisher and the editors reserve the right to keep unsolicited books.

Contact address:

Professor Dr. Konrad Schmid

Theologische Fakultät der Universität Zürich

Kirchgasse 9

CH-8001 Zürich

Switzerland

E-mail: hebai@theol.uzh.ch

Full Text Online

Free access to the full text online is included in a subscription. We ask institutions with more than 20,000 users to obtain a price quote directly from the publisher. Contact: elke.brixner@mohr.de. In order to set up online access for institutions/libraries, please go to: http://www.ingentaconnect.com/register/ institutional. In order to set up online access for private persons, please go to: http://www.ingentaconnect.com/register/personal

Publisher: Mohr Siebeck GmbH \& Co. KG, Postfach 2040, 72010 Tübingen Can be purchased at bookstores.

(C) 2017 Mohr Siebeck GmbH \& Co. KG, Tübingen

The journal and all the individual articles and illustrations contained in it are protected by copyright. Any utilization beyond the narrow confines of copyright law without the publisher's consent is punishable by law. This applies in particular to copying, translations, microfilming and storage and processing in electronic systems.

Printed in Germany.

Typeset by Martin Fischer, Tübingen.

Printed by Gulde-Druck, Tübingen.

ISSN 2192-2276 (Print Edition)

ISSN 2192-2284 (Online Edition) 


\section{Hebrew Bible and Ancient Israel volume 6 (2017), no.2}

\section{Edited by}

Gary N. Knoppers (Notre Dame IN), Oded Lipschits (Tel Aviv), Carol A. Newsom (Atlanta GA), and Konrad Schmid (Zürich)

Hebrew Bible and Ancient Israel is a peer-reviewed, quarterly journal focusing primarily on the biblical texts in their ancient historical contexts, but also on the history of Israel in its own right. Each issue has a topical focus. The primary language is English, but articles may also be published in German and French. A specific goal of the journal is to foster discussion among different academic cultures within a larger international context pertaining to the study of the Hebrew Bible and ancient Israel in the first millennium B.C.E.

Hebrew Bible and Ancient Israel erscheint vierteljährlich, die Beiträge werden durch einen Peer-review-Prozess evaluiert. Ihr Thema sind die Texte der hebräischen und aramäischen Bibel in ihren historischen Kontexten, aber auch die Geschichte Israels selbst. Jedes Heft wird einen thematischen Fokus haben. Die meisten Beiträge werden in Englisch verfasst sein, Artikel können aber auch auf Deutsch oder Französisch erscheinen. Ein besonderes Ziel der Zeitschrift besteht in der Vermittlung der unterschiedlichen akademischen Kulturen im globalen Kontext, die sich mit der Hebräischen Bibel und dem antiken Israel im 1. Jahrtausend v. Chr. beschäftigen.

\section{Associate Editors (2012-2017)}

Erhard Blum, Tübingen; John Day, Oxford; Louis Jonker, Stellenbosch; John Kessler, Toronto; Jacqueline E. Lapsley, Princeton; Martti Nissinen, Helsinki; Thomas Römer, Paris/Lausanne; Christoph Uehlinger, Zürich; David Vanderhooft, Boston; Nili Wazana, Jerusalem 